\title{
TAX INCENTIVES PROVIDED FOR GREEN BONDS IN FINANCING OF ENERGY EFFICIENCY AND ITS IMPORTANCE FOR TURKEY
}

\author{
Ayşe Yí̆it ŞAKAR ${ }^{1}$
}

\begin{abstract}
Energy efficiency is of vital importance for Turkey as one of the elements of sustainable development. Turkey is faced with difficulties in providing sustainable development due to its dependence on imported energy. In addition, the impacts of climate change have a negative effect on Turkey's environment and economy. Turkey is therefore involved in international efforts to combat global climate change and reduce greenhouse gas emissions. As for many countries, financing of energy efficiency is also a significant issue for Turkey. As an alternative to financing energy efficiency, green bonds are developing rapidly all over the world. Green bonds are financial instruments that provide opportunities for investors to participate in the financing of "green" projects that help reduce the negative impacts of climate change and adapt to the impacts of climate change, reduce $\mathrm{CO} 2$ emissions, prevent environmental pollution, and improve social welfare.These structures have important effects on the realization of sustainable development. Turkey's first and only green bond was issued by the Industrial Development Bank of Turkey in 2016 and attracted investors' attention.Countries such as the US, China and Chile apply tax incentives for green bonds to attract investors. However, level of awareness of green bonds in Turkey is low and there are no tax incentives yet. Necessary measures should be taken to facilitate financing of energy efficiency in Turkey and tax incentives should be implemented for green bonds. In this paper, the development and types of green bonds in the world and Turkey, tax incentives provided for green bonds in financing of energy efficiency in the world and Turkey, and recommendations for Turkey were discussed.
\end{abstract}

Keywords: Green bonds, green bond principles, tax incentives, energy efficiency, sustainable energy, sustainable development.

JEL Code: H23, K34, P18, P48, Q01, Q28, Q42, Q48, Q54, Q56

\section{Introduction}

Natural disasters stemmed from climate change in 2017 are estimated to cause US\$320 billion losses (Bahuet, October 8, 2018). Turkey is one of the most affected countries by global climate change, especially by desertification and deterioration of water resources. Therefore, efforts are made at national and international level in order to ensure a sustainable environment and development.Combating climate change is not solely an environmental problem. Within the scope of the combat, the global transition to the low carbon economy will determine the countries' sustainable development, energy, health, agriculture and food security, water resources utilization policies and bring about a social and economic transformation.

Sustainable development can only be successful if environmental, economic and social policies are implemented in a coherent and balanced manner.Energy efficiency is one of the elements of sustainable development. Environmental, economic, political and social concerns increase the importance of energy efficiency policies.

1 Prof. Dr., Istanbul Arel University, aysesakar@arel.edu.tr, ayseyigitsakar@gmail.com 
Recently, green bonds have attracted the attention of investors as a sustainable financing instrument in the financing of energy efficiency investments.Stock markets such as Italy, Oslo, London, Mexico, Luxembourg, Shanghai and Shenzhen have established a certain green bond market segment to strengthen the green bond market (Reboredo, 2018: 39).

Incomes obtained from green bonds are provided with tax incentives in the US, China, India, Brazil and Chile. However, there are no tax incentives in Turkey.In this paper, tax incentives which can be provided to green bonds in the financing of energy efficiency in Turkey and its importance will be discussed.

\section{Methods of Financing Energy Efficiency in Turkey}

Financing of energy efficiency in Turkey is of considerable importance in terms of its benefits and results. In Turkey, which is dependent on foreign energy and whose economy is adversely affected by global climate change, financing energy efficiency projects provides significant and environmental benefits. Energy efficiency projects contribute to the increase of efficiency in the use of energy resources and the reduction of greenhouse gas emissions. They support the reduction of external dependency and current account deficit by ensuring supply security in energy.

Energy efficiency investments in Turkey is not at the desired level due to difficulties arising from access to finance and in order for Turkey to reach its 2023 energy intensity goal, it is necessary to remove the obstacles to the financing of energy efficiency (Ata, 2013: 99).

Basic supports in financing of energy efficiency in Turkey can be listed as such (http://www. yegm.gov.tr/verimlilik/destekler.aspx.):

- Support for Efficiency Enhancing Projects in industrial enterprises.

- Benefiting from 5th Region incentives for Energy Efficiency Investment Projects.

- Support for reducing energy intensity by making Voluntary Agreements for industrial enterprises.

- Support provided for energy efficiency projects by the industrial enterprises of Technology Development Foundation of Turkey.

- Support provided by KOSGEB to small and medium enterprises for surveys and energy efficiency consultancy services taken from energy efficiency consultancy companies.

- Loans provided by international development agencies and financial institutions and by national banks and financial institutions under favorable conditions.

In addition, green bonds began to be used more and more in the financing of energy efficiency in Turkey and worldwide. 


\section{Green Bonds in Financing Energy Efficiency}

\subsection{The Concept of Green Bond and its Development}

A green bond is a debt security that is issued to raise capital specifically to support climate related or environmental projects (IBRD, 2015: 23; Berensmann vd., 2016: 2; Kandır \&Yakar, 2017a: 161;Tang \& Zhang, 2018: 4). This financial instrument is attractive as an alternative investment tool for investors focusing on integrating Environmental-Social-Governance issues into investment processes in international financial markets (ESCARUS, 2018: 42).Green bonds are financial instruments that provide opportunities for investors to participate in the financing of "green" projects that help reduce the negative impacts of climate change and adapt to the impacts of climate change(Reichelt, 2010: 2; Tang \& Zhang, 2018: 4; Kandır\&Yakar, 2017a: 161).

Green Bonds can be defined as "any type of bond instrument where the proceeds will be exclusively applied to finance or re-finance, in part or in full, new and/or existing eligible Green Projects and which are aligned with the four core components of the GBP" (International Capital Market Association, 2018).

A key feature of these bonds valued by many investors is the due diligence process that the issuer of green bonds conducts to identify and monitor 'green' projects (Reichelt, 2010: 2).The difference of green bonds from other bonds is that the funds obtained from the bond issuance must be used in green projects (Kandır \&Yakar, 2017 b: 92).

As can be seen in Table 1, renewable energy and energy efficiency investments have the largest share. In 2017, the share of renewable energy decreased by $3.7 \%$, while the share of energy efficiency increased by $2.4 \%$ compared to 2016 .

Table 1. Comparison of use of proceeds for 2016 and 2017

\begin{tabular}{|l|l|l|}
\hline & $\mathbf{2 0 1 6}$ & $\mathbf{2 0 1 7}$ \\
\hline Renewable Energy & $29.1 \%$ & $25.4 \%$ \\
\hline Energy Efficiency & $19.4 \%$ & $21.8 \%$ \\
\hline Clean Transportation & $14.02 \%$ & $14.06 \%$ \\
\hline Sustainable Water Management & $11.2 \%$ & $9.95 \%$ \\
\hline Pollution Prevention and Control & $11.3 \%$ & $9.95 \%$ \\
\hline Terrestrial and Aquatic Biodiversity Conservation & $2.1 \%$ & $7.8 \%$ \\
\hline $\begin{array}{l}\text { Eco-Efficient Products, Production Technologies and } \\
\text { Processes }\end{array}$ & $1.2 \%$ & $5.6 \%$ \\
\hline Sustainable Management of Living Natural Resources & $2.1 \%$ & $5.24 \%$ \\
\hline Climate Change Adaptation & $5.6 \%$ & $0.2 \%$ \\
\hline
\end{tabular}

Reference: Green Bonds: Review of 2017, s. 11. https://www.environmental finance. com/assets/files/Green\%20Bonds\%20Review\%20of\%202017.pdf (16.02.2019).

Private sector, international financial institutions, supranational institutions as well as national level states, regional governments and municipalities can also issue green bonds (Flaherty vd., 2017: 471-472). As seen from Table 2, while financial institutions had the largest share with $36.45 \%$ of green bond issuers in 2016, its share in 2017 decreased to $16.59 \%$. The most drastic increase in green bond issuance in 2017 occurred in agency and sovereign bonds. 
Table 2. Comparison of issuer types (2016-2017)

\begin{tabular}{|l|l|l|}
\hline & $\mathbf{2 0 1 6}$ & $\mathbf{2 0 1 7}$ \\
\hline Agency & $10 . \%$ & $31.27 \%$ \\
\hline Corporate & $31.5 \%$ & $29.73 \%$ \\
\hline Financial Institution & $36.45 \%$ & $16.59 \%$ \\
\hline Municipal & $10.5 \%$ & $8.9 \%$ \\
\hline Sovereign & $0.85 \%$ & $7.07 \%$ \\
\hline Supranational & $10.5 \%$ & $6.41 \%$ \\
\hline
\end{tabular}

Reference: Green Bonds: Review of 2017, s. 11. https://www.environmental finance.com/assets/files/Green\%20Bonds\%20Review\%20of\%202017.pdf (16.02.2019).

The global green bond market started in 2007 with an issue from the European Investment Bank. In 2008, the World Bank issued the first fixed-rate bond carrying a green label (Chiang, 2017: 8).

Poland was the first national government to issue a green bond valued US\$800 million in December 2016. It was followed in January 2017 by France. Argentina, Chile, Fiji, Lithuania, Malaysia, Nigeria, Singapore, Switzerland and the UAE joined the fray in 2017 (Green Bonds: Review of 2017, s. 3). In March 2018, the Government of Indonesia issued the first Green Islamic Bond (green sovereign sukuk).The five-year issuance reached US\$1.25 billion (Bahuet, October 8, 2018).

The US, China and France are the leading countries in the green bond market. China's first green bonds were issued in 2015 (Boulle vd, 2017: 4). Whereas in the US and China, issuers were mainly agencies and financial institutions in 2017, French issuers were more diverse. The French sovereign bond accounts for $53 \%$ of the value of issuance from the country, but corporates account for $32 \%$, agencies $10 \%$, and financial institutions and municipals the remaining $5 \%$ (Green Bonds: Review of 2017: 3).

The first green municipality bond was issued in June 2013 in Massachusetts. In October 2013, Gothenburg issued its green city bond.There are different US states, Ontario state (Canada), Johannesburg city (South Africa) and La Rioja state (Argentina) among the large scale green bond issuers. The green bond issuance of regional governments is also ongoing (ESCARUS, 2018: 39).

In May, $18^{\text {th }} 2016$, Industrial Development Bank of Turkey was the first to issue 5-year term $\$ 300$ million green/sustainable bond. $44 \%$ of the demand for bond issue came from England, $39 \%$ from Continental Europe, 9\% from US off-shore funds, 8\% from Asia and the Middle East (TSKB, 2017: 13).

\subsection{The Green Bond Principles}

In 2014, the Green Bond Principles, which are in the form of advice and voluntary guidance, have been formed (Ceres, 2014: 1). Green Bond Principles are designed for the development of the green bond market. The issuers are guided and supported at the key points when issuing green bonds. It proposes the transparency, sharing and integrity of the information to be reported to the stakeholders by the issuers (International Capital Market Association, 2018). Green Bond 
helps investors by ensuring the availability of information necessary to assess the environmental impact of their investments and helps the insurance companies by moving the market towards standard explanations to facilitate transactions (Ceres, 2014: 1).

The GBP have four core components:

1. Use of Proceeds

2. Process for Project Evaluation and Selection

3. Management of Proceeds

4. Reporting

\subsection{Types of Green Bonds}

There are four types of Green Bonds (International Capital Market Association, 2018).

- Standard Green Use of Proceeds Bond: It is the obligation of a standard recourse debt to the issuer aligned with the green bond principles.

- Green Revenue Bond: It is the obligation of a standard non-recourse debt to the issuer aligned with the green bond principles in which the credit risk in the bond depends on pledged cash flows of inflows, wages, taxes, etc. and where their income is used for the relevant or unrelated green project(s).

- Green Project Bond: It is the project bond that complies with the principles of green bonds for one or more green projects where the investor will be directly exposed to the risk of project/projects with or without potential recourse to the issuer.

- Green Securitised Bond: It is the bond secured by one or more specific green projects, such as covered bonds, ABS, MBS, and other structures and aligned with the GBP.

Green bonds are also classified as labeled and unlabeled green bonds. While labeled green bonds can be marketed as green bonds, unlabled green bonds cannot be marketed as green bonds in the capital market, although they are used to finance environmentally friendly projects as labeled bonds (Kandır\&Yakar, 2017b: 94).

\subsection{Tax Incentives Provided For Green Bonds in the World and Turkey}

There are various tax incentives provided to investors or issuers for green bonds (https://www. climatebonds.net/policy/policy-areas/tax-incentives):

- Tax credit bonds: Bond investors receive tax credits instead of interest payments. An example of this in the clean energy field is the US Federal Government's Clean Renewable Energy Bonds (CREBs) and Qualified Energy Conservation Bonds (QECBs) program. In the program, the issuance of tax credit bonds of municipalities is allowed; $A$ tax credit of up to $70 \%$ of the coupon is subsidized by the municipality or the federal government.

- Direct subsidy bonds: Bond issuers receive cash back from the state to subsidize net interest payments. In addition, this structure is used under the US federal government Clean Renewable Energy Bonds (CREBs) and Qualified Energy Conservation Bonds (QECBs) program.

- Tax-exempt bonds: Bond investors do not have to pay income tax on interest from their green bonds (which may lower the issuer's interest rate). 
All green bonds issued in China, Chile, India, USA and Brazil are exempt from tax, whereas in Malaysia, tax deductions are applied. (International Institute for Sustainable Development, 2016). In Turkey, however, there is no special provision and tax incentive in our tax legislation for the revenues derived from green bonds (Kandır\&Yakar, 2017 a:103). Revenues obtained from government bonds and special bonds are subject to withholding according to the provisional article 67 of Income Tax Law. (Gelir İdaresi Başkanlığı, 2019: 8-10). Revenues obtained from green bonds are also subject to tax.

\section{Conclusion}

In many countries around the world, interest in green bonds is increasing and this market is growing in order to combat climate change, to get rid of the dependence on fossil fuels in energy and to ensure sustainable development. In 2016, Industrial Development Bank of Turkey (TSKB) became the first establishment in Turkey to issue green bonds. There are countries such as Poland and France which issue sovereign bonds, however, Turkey is not one of them. In terms of our country, which is dependent on foreign resources in energy and which has current account deficit, it is important to strengthen and encourage green bond market as an option for financing energy efficiency. Issuing green bonds in Turkey does not provide any tax benefits for investors. For the reasons mentioned above, tax incentives should be used as tools to be able to benefit from green bonds in financing energy efficiency and to improve green bond market (See. Kandır\&Yakar, 2017 a: 104).

\section{References}

Ata, S.U. (2013). “Sürdürülebilir Enerjinin Finansmanı", Türkiye'de İklim Değişikliği ve Sürdürülebilir Enerji, (Ed.) Ediger, V. Ş., İstanbul, ENiVA-Enerji ve İklim Değişikliği Vakfi, ss.99-119.

Bahuet, C. (October 8, 2018). Indonesia's green sukuk, https://www.undp.org /content/undp/en/home/blog/2018/Indonesias-green-sukuk.html (20.02.2019).

Berensmann, K., Dafe F. , Kautz M. \& Lindenberg N. (2016). Green bonds: taking off the rosecoloured glasses, Briefing Paper, 24/2016, Department "World Economy and Development Financing", German Development Institute / Deutsches Institut für Entwicklungspolitik (DIE). http://www.die-gdi.de/uploads/media/BP_24.2016.pdf (28.01.2019).

Boulle, B., Dai, L. \& Meng, A (2017). China Green Bond Market 2016, Climate Bonds Initiative \& The China Central Depository \& Clearing Company (CCDC), January. https://www. climatebonds.net/resources/reports/china-green-bond-market-2016-0 (22.02.2019).

Ceres (2014). Green Bond Principles, 2014, Voluntary Process Guidelines for Issuing Green Bonds, Ceres Report, January 13, 2014. https://www.ceres.org/sites/default/files/reports/2017-05/ Green\%20Bond \%20 Principles.pdf (18.02.2019).

Chiang, J. (January 2017). Growing the U.S. Green Bond Market: Volume 1, California State Treasurers Office. http://treasurer.ca.gov/greenbonds/publications/reports/1.pdf (18.02.2019).

ESCARUS (2018). Dönüşen Dünyada Fırsatları Yakalamak: Sürdürülebilir Finans Görünümü , Eylül 2018. İstanbul. http://www.escarus.com/raporlar-ve-analizler (17.02.2019). 
Flaherty, M. , Gevorkyan, A. Radpour, S. \& Semmler, W. (2017). Financing climate policies through climate bonds - A threestage model and empirics, Research in International Business and Finance, 42 (2017), pp. 468-479.

Gelir İdaresi Başkanlığı (2019).G.V.K. Geçici 67 nci Madde Uygulaması Ile Ilgili Olarak Gerçek Kişilere Yönelik Vergi Rehberi, Mükellef Hizmetleri Daire Başkanlığı Yayın No: 313 Şubat 2019, Ankara.

Green Bonds: Review of 2017. https://www.environmental finance.com/assets/files/Green\%20 Bonds\%20Review\%20of\%202017.pdf (16.02.2019).

https://www.climatebonds.net/policy/policy-areas/tax-incentives (15.01.2019).

http://www.yegm.gov.tr/verimlilik/destekler.aspx. (20.02.2019).

IBRD (2015). What Are Green Bonds?, International Bank for Reconstruction and Development -The World Bank, Washington, http://documents.worldbank.org/curated /en/400251468187810398/pdf/99662-REVISED-WB-Green-Bond-Box393208B-PUBLIC. pdf (15.02.2019).

International Capital Market Association (June, 2018), Green Bond Principles Voluntary Process Guidelines for Issuing Green Bonds, https://www.icmagroup.org/green-social-andsustainability-bonds/green-bond-principles-gbp/ (16.02.2019).

Kandır, S.Y. \& Yakar, S. (2017a). "Yeşil Tahvil Piyasaları: Türkiye'de Yeşil Tahvil Piyasasanın Geliştirilebilmesi İçin Öneriler", Ç.Ü. Sosyal Bilimler Enstitüsü Dergisi, 26 (2), ss. 159-175.

Kandır, S.Y. \& Yakar, S. (2017 b). “Yenilenebilir Enerji Yatırımları İçin Yeni Bir Finansal Araç: Yeşil Tahviller", Maliye Dergisi, 172, ss. 85-110.

Reichelt, H. (2010). Green Bonds : A Model to Mobilize Private Capital to Fund Climate Change Mitigation and Adaptation Projects (English). Euromoney Handbook. Washington, D.C. : World Bank Group. http://documents.worldbank.org/curated/en/ 680921507013408005/ Green-bonds-a-model-to-mobilize-private-capital-to-fund-climate-change-mitigation-andadaptation-projects (22.02.2019)

Reboredo, J. C. (August, 2018). "Green Bond and Financial Markets: Co-Movement, Diversification and Price Spillover Effects", Energy Economics, (74), pp.38-50, https://doi.org/10.1016/j. eneco.2018.05.030 (05.01.2019).

Tang, D.Y. \&, Zhang, Y. (2018). “Do shareholders benefit from green bonds?”, Journal of Corporate Finance (Corfin), Artical in press, https://doi.org/10.1016/j.jcorpfin. 2018.12.001.

TSKB (2017). Green/ Sustainable Bond, Allocation \& Impact Reporting 2017. http://www.tskb. com.tr/web/101-3133-1-1/tskb-site-tr/tr-hakkimizda/tskbden-haberler/yesil/surdurulebilirtahvil-ile-yaratilan-degeri-anlatan-allocation-impact-reporting-2017-yayinlandi (20.02.2019). 